\title{
Ultrasonography of Uterine Involution in Goats
}

\author{
Ivan FASULKOV* \\ Department of Obstetrics, Reproduction and Reproductive Disorders, Faculty of Veterinary Medicine, Trakia University, \\ Student s Campus, 6000 Stara Zagora, Bulgaria \\ *Corresponding Author: Ivan FASULKOV Department of Obstetrics, Reproduction and Reproductive Disorders, Faculty of \\ Veterinary Medicine, Trakia University, Student`s Campus, 6000 Stara Zagora, Bulgaria. \\ e-mail: i.fasulkov@gmail.com
}

Geliș Tarihi / Received: 19.11.2012

\begin{abstract}
The purpose of the study was to investigate the uterine involution in goats from a local Bulgarian breed through ultrasonography. Six goats from a local breed, 3 to 7 years of age, weighing 42-60 kg, housed in the Production Animal Farm of the Faculty of Veterinary Medicine, Trakia University, Stara Zagora, were included in the experiment. Ultrasonography was performed with Aloka SSD 500 Micrus (Tokyo, Japan) ultrasound and a $5 \mathrm{MHz}$ linear transducer. Goats were examined in standing position for the transabdominal approach, and when the visualisation of studied structures was impossible, the transrectal approach was used. Uterine involution in goats was evaluated by serial ultrasound examinations at days $1,3,6,9,12,15,20$ and 30 postpartum. The outer and inner diameters of the caruncles, uterine body lumen, and uterine wall thickness were measured. The visualisation of outer and inner caruncular diameters was possible until the 9th day postpartum. The ultrasound measurement of uterine lumen diameter, outer and inner caruncular diameters revealed a statistically significant reduction in their size $(\mathrm{P}<0.05)$ as early as the 3rd day compared to the 1 st day postpartum. Uterine wall was considerably thinner $(\mathrm{P}<0.05)$ by the 9 th day after the parturition. The evaluation of results suggested that ultrasonography could be an alternative for monitoring the uterine involution in goats to slaughter.
\end{abstract}

Key Words: Ultrasonography, uterine involution, puerperium, goats

\section{ÖZET}

\section{KEÇILERDE UTERUS INVOLÜSYON ULTRASONOGRAFISİ}

$\mathrm{Bu}$ araştırma, yerel Bulgar ırkı keçilerde ultrasonografi yöntemi ile uterus involüsyonunun araştırılması için yapılmıştır. Stara Zagora, Trakya Üniversitesi Veteriner Fakültesi Hayvan Üretim Çiftliğinde bulunan 3 ile 7 yaş arasında ve 42 ile $60 \mathrm{~kg}$ ağırlı̆̆ında 6 adet lokal ırk keçi ile deneme gerçekleştirilmiştir. Ultrasonografi, Aloka SSD 500 Micrus (Tokyo, Japonya) ultrason ve $5 \mathrm{MHz}$ 'lik bir lineer dönüştürücü ile yapılmıştır. Keçiler ayakta durma pozisyonunda transabdominal şekilde muayene edilirken, incelenen yapıların görüntülenmesinin imkansız olduğu durumda, transrektal uygulama kullanılmıştır. Keçilerde uterus involüsyonu, seri ultrason denemeleri ile doğum sonrası $1,3,6,9,12,15,20$ ve 30. günlerde değerlendirilmiştir. Karinkullerin dış ve iç çapları, uterus gövde boşluğu ve uterus duvarının kalınlığı ölçülmüştür. Karinkulalların dış ve iç çağları doğum sonrası 9. güne kadar görüntülenmiştir. Doğum sonrası 1. ile 3. gün karşılaştırıldığında, ultrason ile ölçümde uterus boşluğu çapı, dış ve iç karinkulaların boyutları arasında istatistiksel olarak önemli bir farklılık $(\mathrm{P}<0,05)$ olduğu ortaya konmuştur. Doğum sonrası 9. güne kadar uterus duvarı oldukça incelmiştir $(\mathrm{P}<0,05)$. Bulguların değerlendirilmesi doğrultusunda, ultrasonografinin keçilerde kesime kadar uterus involüsyonunun izlenmesinde alternatif olarak kullanılabileceği önerilmektedir.

Anahtar Kelimeler: Ultrasonografi, uterus involusyonu, doğum, keçi 


\section{Introduction}

The reproductive performance of small ruminants is of great economic significance, as it determines the annual offspring number (Greyling, 2000).

Ultrasonography was originally used in animal reproduction to detect pregnancy in horses (Palmer and Driancourt, 1980) and cats (Mailhac et al., 1980). It is a rapid, accurate non-invasive diagnostic means for identification of physiological and pathological changes of the genital tract of small ruminants as well (Dimitrov et al., 2002; Hesselink and Taverne, 1994; Kähn, 1992; Kähn, 2004; Yotov, 2011).

The decrease (reduction) of the size of genitals is called involution, which occurs on a decreasing logarithmic scale with most significant change during the first post partum days. Uterine contractions last for several days, although with decreasing frequency, amplitude and duration (Noakes, 2009).

The uterine diameter and shape, uterine wall echostructure and layers, and the fluid accumulation into the uterine lumen were initially investigated in cattle (Okano and Tomizuka, 1987), sows (Irie, 1987) and dogs (Yeager and Concannon, 1990). These studies provide evidence that ultrasonography could be used for evaluation of the course and the end of uterine involution.

In small ruminants, involution is characterized with rapid reduction of uterine size and contraction rates, most commonly between the 3rd and the 10th days postpartum, as indicated by measurements of uterine weight and length, uterine body and gravid horn diameters (Noakes, 2009). The research in this field shows that in goats, uterine involution was completed by the 16th (Sanchez et al., 2002), 19th (Baru et al., 1983; Degefa, 2003; Degefa et al., 2006) or the 28th (Greyling and van Niekerk, 1991; Tielgy et al., 1982) days postpartum based on slaughterhouse findings. Other techniques used for follow-up of the course of uterine involution in small ruminants were assay of hormones and their metabolites (Degefa, 2003; Ishwar, 1995), radiography
(Goddard, 1995; Kene, 1991; Tian and Noakes, 1991) and laparotomy (Ishwar, 1995).

The purpose of the present study was to monitor the course of uterine involution in goats from a local Bulgarian breed by ultrasonography.

\section{Materials and Methods}

\section{Experimental animals and equipment}

The study was conducted with 6 goats from a local breed, 3 to 7 years of age, weighing 42$60 \mathrm{~kg}$, fed and housed uniformly in the Production Animal Farm of the Faculty of Veterinary Medicine, Trakia University, Stara Zagora.

The ultrasound imaging studies were done with Aloka SSD 500 Micrus (Tokyo, Japan) equipment and a $5 \mathrm{MHz}$ linear transducer. Findings were documented on a thermal printer Mitsubishi P91 E (Tokyo, Japan).

\section{Experimental design}

The course of uterine involution in goats was monitored by single individual ultrasound examination at days $1,3,6,9,12,15,20$ and 30 postpartum.

The dimensions of the following parameters were measured:

- $\quad$ outer diameter of the caruncle;

- inner diameter of the caruncle;

- diameter of uterine body lumen;

- uterine wall thickness.

Ultrasonography was initially performed via the transabdominal approach after contact gel (Eco-ultra gel, Milano, Italy) application for better contact between the skin and the transducer. When the visualisation of studied structures was impossible, the transrectal approach was used.

\section{Statistical analysis}

The data were processed by the StatSoft (Microsoft Corp. 1984-2000 Inc.) statistical software. ANOVA and non-parametric comparison of proportions using the Student's $t$ 
criterion were used. Differences were considered statistically significant at $\mathrm{P}<0.05$.

\section{Results}

The ultrasonographic examination on the first day postpartum using the transabdominal approach showed clearly the caruncles, the uterine lumen and wall. Caruncles and uterine wall were hypoechoic, whereas the uterine lumen was filled with anechoic fluid (Figure 1).
Reduced uterine body lumen and amount of anechoic uterine fluid were visualised on ultrasonographies performed on different days of the puerperium $(1,3,6,9,12,15,20$, and 30$)$ (Figure 2).

The ultrasound-measured dimensions of the different uterine parameters in goats after the parturition are presented in Table 1.

Table 1. Dimensions of studied parameters in goats $(n=6)$ after the parturition.

Tablo 1. Keçilerde $(\mathrm{n}=6)$ doğum sonrası incelenen parametrelerin boyutları.

\begin{tabular}{|c|c|c|}
\hline Parameter & Day of postpartum & Mean ( \pm SEM) \\
\hline \multirow{4}{*}{ Outer diameter of the caruncle $(\mathrm{cm})$} & 1 & $2.86( \pm 0.43)$ \\
\hline & 3 & $2.27( \pm 0.26)^{*}$ \\
\hline & 6 & $1.81( \pm 0.12)^{* * *}$ \\
\hline & 9 & $1.33( \pm 0.22)$ \\
\hline \multirow{4}{*}{ Inner diameter of the caruncle $(\mathrm{cm})$} & 1 & $1.39( \pm 0.08)$ \\
\hline & 3 & $0.64( \pm 0.11)^{* * *}$ \\
\hline & 6 & $0.75( \pm 0.09)$ \\
\hline & 9 & $0.54( \pm 0.1)$ \\
\hline \multirow{8}{*}{ Uterine wall thickness $(\mathrm{cm})$} & 1 & $0.47( \pm 0.1)$ \\
\hline & 3 & $0.42( \pm 0.009)$ \\
\hline & 6 & $0.38( \pm 0.04)$ \\
\hline & 9 & $0.36( \pm 0.03) *$ \\
\hline & 12 & $0.39( \pm 0.06)$ \\
\hline & 15 & $0.30( \pm 0.02)^{* *}$ \\
\hline & 20 & $0.29( \pm 0.04)$ \\
\hline & 30 & $0.26( \pm 0.02)^{* * *}$ \\
\hline \multirow{8}{*}{ Uterine lumen diameter $(\mathrm{cm})$} & 1 & $1.95( \pm 0.41)$ \\
\hline & 3 & $1.03( \pm 0.02)^{* * *}$ \\
\hline & 6 & $0.96( \pm 0.07)$ \\
\hline & 9 & $0.77( \pm 0.2)$ \\
\hline & 12 & $0.77( \pm 0.12)$ \\
\hline & 15 & $0.65( \pm 0.11)$ \\
\hline & 20 & $0.59( \pm 0.1)$ \\
\hline & 30 & $0.48( \pm 0.1)$ \\
\hline
\end{tabular}

By the 1st day postpartum, the average uterine lumen diameter was $1.95( \pm 0.41) \mathrm{cm}$. A significant regression of its size $(\mathrm{P}<0.001)$ occurred as early as the 3rd day postpartum $1.03( \pm 0.02) \mathrm{cm}$, while its average size on the 30th day was $0.48( \pm 0.1) \mathrm{cm}$.
The uterine wall thickness in goats was $0.47( \pm 0.1) \mathrm{cm}$ on the day after parturition. Statistically significant differences vs day 1 thickness was observed by the 9th day postpartum $(\mathrm{P}<0.05)$. Even greater differences were registered on days $15(\mathrm{P}<0.01)$ and 30 $(\mathrm{P}<0.001)$ postpartum. 


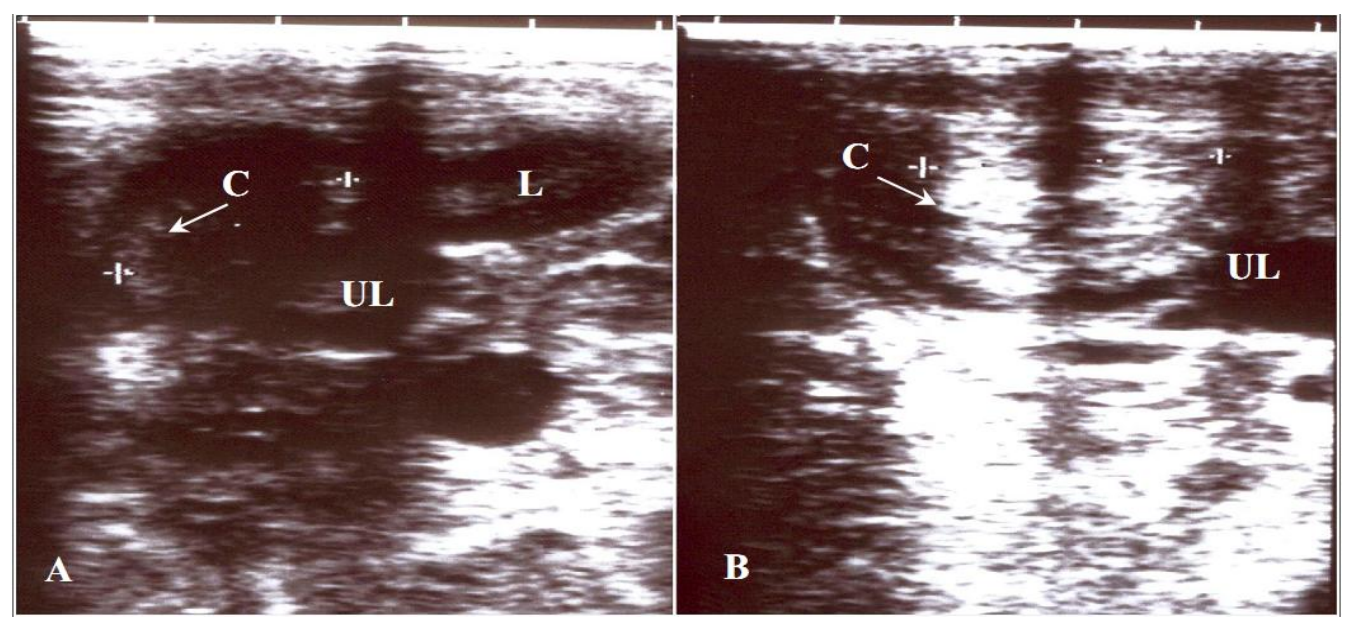

Figure 1. Ultrasonography of the uterus in a goat by the $1^{\text {st }}$ day postpartum (transabdominal approach, $5 \mathrm{MHz}$ linear transducer).

A-post partum day 1; B-post partum day 3; C-caruncle; L-lochia; UL-gravid horn lumen.

Şekil 1. Doğum sonrası 1. günde keçide uterusun ultrasonografisi (transabdominal şekilde, $5 \mathrm{MHz}$ lineer dönüştürücü).

A-Doğum sonrası 1. gün; B-Doğum sonras1 3. gün; C-Karinkul; L-Akıntı; UL-gebe uterus boynuz bölümünün boşluğu

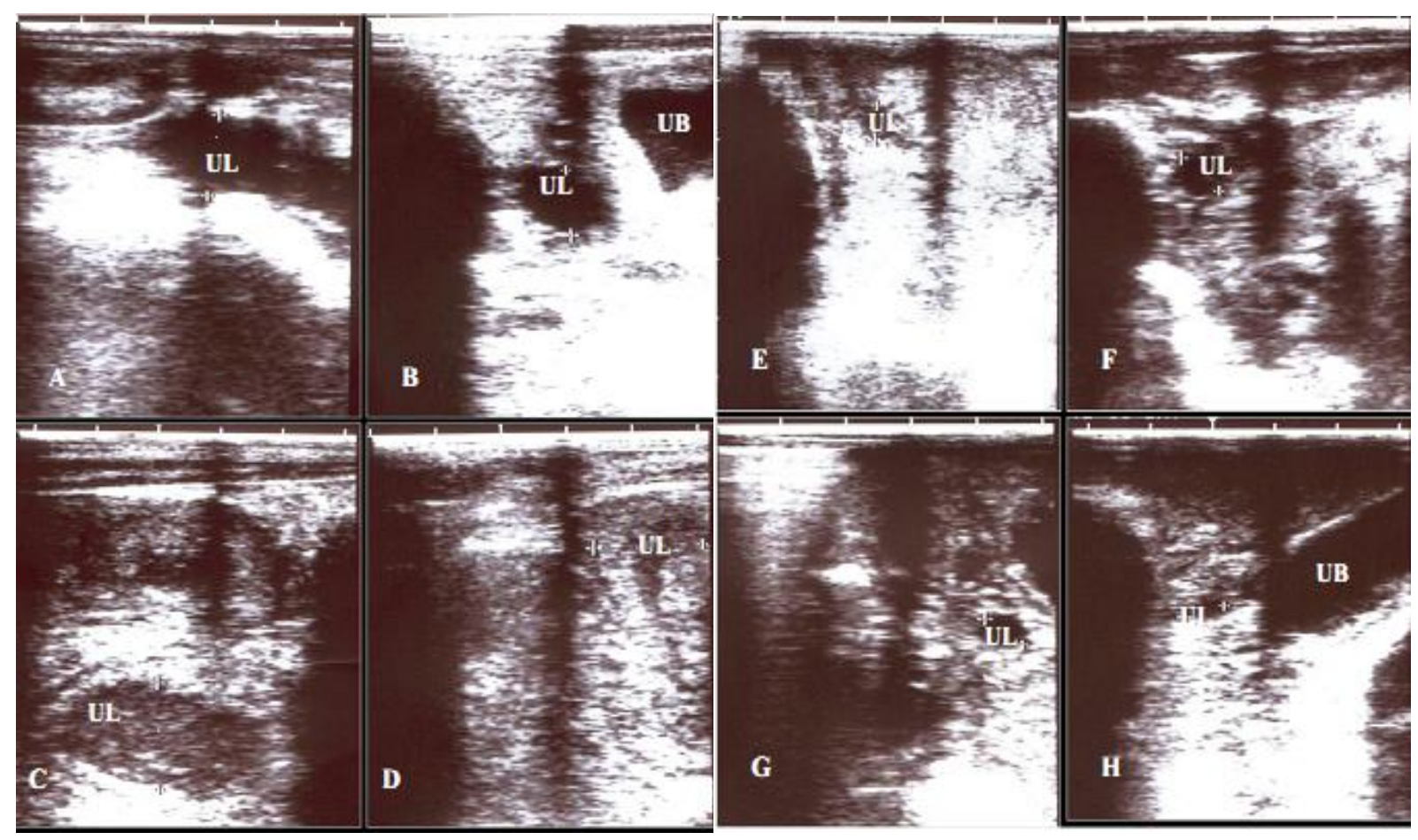

Figure 2. Ultrasonography of the uterine lumen in a goat during the postpartum period.

A - day 1; B - day 3; C - day 6; D - day 9; E - day 12; F - day 15; G - day 20; H - day 30. $\mathrm{UL}$ - uterine lumen; UB - urinary bladder.

Şekil 2. Doğum sonrası periyod sırasında keçide uterus boşluğunun ultrasonografisi.

A - gün 1; B - gün 3; C - gün 6; D - gün9; E - gün 12; F - gün 15; G - gün 20; H - gün 30.

UL - uterus boşluğu lumen; UB - idrar kesesi. 
The outer caruncular diameter on the 1st day postpartum averaged $2.86( \pm 0.43) \mathrm{cm}$. By day 3 , its size was considerably $(\mathrm{P}<0.05)$ reduced$2.27( \pm 0.26) \mathrm{cm}$. This parameter could be determined until the 9th day after the parturition, when its average size was $1.33( \pm 0.22) \mathrm{cm}$.

The inner diameter of the caruncle as measured by ultrasound was $0.64( \pm 0.11) \mathrm{cm}$ on the 3rd day postpartum, i.e. substantially lower $(\mathrm{P}<0.001)$ vs its size on the day after parturition $1.39( \pm 0.08) \mathrm{cm}$. The visualisation of the parameter was possible up to the 9th day postpartum, when its average size was $0.54( \pm 0.1) \mathrm{cm}$.

\section{Discussion}

There are only few reports on the potential of ultrasound imaging for monitoring of postparturient uterine involution in sheep and goats (Ababneh and Degefa, 2005; Hauser and Bostedt, 2002; Zduńczyk et al., 2004). Most studies on these events were based on gross post slaughter examinations of experimental animals.

Ababneh and Degefa (2005) used transabdominal and transrectal ultrasonography to measure the diameters of gravid and nongravid uterine horns 1, 2, 4, 7, 10, 13, 19 and 25 days postpartum in Baladi goats. They reported a strong positive correlation $(r>0.95)$ between the post-slaughter outer uterine circumference and ultrasound measurements.

The close relationship between ultrasonographic data and gross measurements showed that ultrasonography could be reliable for field monitoring of the uterine involution and could be an alternative to post slaughter studies (Ababneh and Degefa, 2005). Viñoles-Gil et al. (2010) also confirmed that transrectal ultrasonography was an appropriate method for uterine horns measurement in the follow-up of postparturient uterine involution.

The ultrasound imaging of caruncles in our study was possible until the 9th day postpartum. Similar regression of caruncles and uterine lumen fluid during the first week postpartum was reported in the study of Ababneh and Degefa (2005).

The average outer caruncular diameter was $2.86( \pm 0.43) \mathrm{cm}$ on the day after the parturition with marked regression $(\mathrm{P}<0.001)$ by the 9th day postpartum $1.33( \pm 0.22) \mathrm{cm}$. Our data supported the findings of Hauser and Bostedt (2002), which assumed that ultrasound differentiation and accurate measurement of caruncles were possible until the 8th day postpartum. The authors reported caruncular sizes of $2.02( \pm 0.16) \mathrm{cm}$ and $1.24( \pm 0.17) \mathrm{cm}$ by the 1 st and 8th days postpartum respectively in ewes.

The analysis of our results indicates a clear tendency towards reduction of all measured parameters during the first week postpartum. A statistically significant difference $(\mathrm{P}<0.05)$ vs the day after parturition was demonstrated as early as the second ultrasonography (3rd day postpartum). Only uterine wall thickness exhibited the first substantial difference by the 9th day postpartum.

Our data are in agreement with those of Degefa et al. (2006), who outlined three stages of involution in Baladi goats - a rapid stage until the 7 th day, a moderate regression stage until the 13th day and ending stage by the 19th day postpartum. The results of Ababneh and Degefa (2005) also evidenced a significantly more rapid regression until the 7 th day as compared to the 7-19 days postpartum interval. According to most researchers, uterine regression is completed about 17 to 19 days after the parturition (Ababneh and Degefa, 2005; Degefa et al., 2006; Hauser and Bostedt, 2002).

\section{Conclusion}

The evaluation of results showed that ultrasonography is a fast, accurate non-invasive tool for monitoring uterine involution in goats. For this purpose, the outer and inner diameters of the caruncle, uterine wall thickness and uterine lumen diameter could be used.

The visualisation of the outer and inner caruncular diameters was possibly only until the 9th day postpartum. The uterine body 
lumen, and outer and inner caruncular diameters regressed statistically significantly $(\mathrm{P}<0.05)$ as early as the 3rd day postpartum compared to the day after the parturition. Uterine wall thickness was considerably reduced $(\mathrm{P}<0.05)$ by the 9 th day of postpartum.

In conclusion, we suggest that ultrasonography could be an alternative to slaughter for monitoring the normal course of uterine involution in goats. Future topics of interest would be the ultrasonography of these parameters in pathological states during and after the parturition, leading to disturbances in the normal uterine involution.

\section{REFERENCES}

Ababneh, M.M., Degefa, T., 2005. Ultrasonic assessment of puerperal uterine involution in Balady goats. Journal of Veterinary Medicine A 52, 244-248.

Baru, P., Khar, S.K., Gupta, R.C., Luthra, R.A., 1983. Uterine involution in goats, agricultural practice. Veterinary Medicine \& Small Animal Clinician 11, 1773-1776.

Degefa, T., 2003. Postpartum uterine involution in goat in Jordan. Masters Thesis, Jordan University of Science and Technology, Irbid, Jordan.

Degefa, T., Ababneh, M.M., Moustafa, M.F., 2006. Uterine involution in the post-partum Balady goat. Veterinarski Archiv 76 (2), 119-133.

Dimitrov, M., Vassilev, N., Georgiev, P., Ivanov, I., Yotov, S., 2002. Ultrasonographic assessment of early pregnancy in animals. Bulgarian Journal of Veterinary Medicine 5 (3), 167-178.

Goddard, P.J., 1995. Veterinary Ultrasonography. CAB International, Willington, UK.

Greyling, J.P.C., 2000. Reproduction traits in the Boar goat doe. Small Ruminant Research 36, 171177.

Greyling, J.P.C., van Niekerk, C.H., 1991. Macroscopic uterine involution in the postpartum Boar goat. Small Ruminant Research 4, 277-283.

Hauser, B., Bostedt, H., 2002. Ultrasonographic observations of the uterine regression in the ewe under different obstetrical conditions. Journal of Veterinary Medicine A 49, 511-516.

Hesselink, J.W., Taverne, M.A.M., 1994. Ultrasonography of the uterus of the goat. Veterinary Quarterly 16 (1), 41-45.
Irie, M., 1987. Observations on the uterus of postpartum sows using a linear electronic scanner. Japanese Journal of Zootechnical Science 58, 407-412.

Ishwar, A.K., 1995. Pregnancy diagnosis in sheep and goats: a review. Small Ruminant Research 17, 37-44.

Kähn, W., 1992. Ultrasonography as a diagnostic tool in female animal reproduction. Animal Reproduction Science 28, 1-10.

Kähn, W., 2004. Ultrasonography in sheep and goats. In: Kähn, W. (Ed.), Veterinary Reproductive Ultrasonography. Hannover, Schlütersche Verlagsgesellschaft mbH \& Co., pp. 187-210.

Kene, R.O.C., 1991. Radiographic investigation of dystocia in the West Africa Dwarf Goat. British Veterinary Journal 147, 283-289.

Mailhac, J.M., Chaffaux, S., Legrand, J.J., Carlier, B., Heitz, F., 1980. Diagnostic de la gestation chez la chatte: utilization de l'échographie. Recueil de Medecine Veterinaire d'Alfort 156, 899-907.

Noakes, D., 2009. The puerperium. In: Noakes, D.E., Parkinson, T.J., England, G.C.W. (Eds.), Veterinary reproduction and obstetrics, ninth edition. Philadelphia, W.B. Saunders, pp. 194205.

Okano, A., Tomizuka, T., 1987. Ultrasonic observation of postpartum uterine involution in the cow. Theriogenology 27 (2), 369-376.

Palmer, E., Driancourt, M.A., 1980. Use of ultrasonic echography in equine gynecology. Theriogenology 13, 203-216.

Sanchez, M.A., Garcia, P., Menendez, S., Sanchez, B., Gonzalez, M., Flores, J.M., 2002. Fibroblastic growth factor receptor (FGF-R) expression during uterine involution in goat. Animal Reproduction Science 69, 25-35.

Tian, W., Noakes, D.E., 1991. A radiographic methods for measuring the effect of exogenous hormone therapy on uterine involution in ewes. Veterinary Record 129, 463-466.

Tielgy, A.H., Fathalla, M., Omar, M.A., Al-Dahash, S., 1982. The clinical and morphological characteristics of the uterus of the goat during the period of involution. The Canadian Veterinary Journal 23, 138-140.

Viñoles-Gil, C., Gonzalez-Bulnes, A., Martin, G.B., Zlatar, F.S., Sale, S., 2010. Sheep and goats. In: DesCôteaux, L., Gnemmi, G., Colloton, G. (Eds.), Practical Atlas of Ruminant and Camelid Reproductive Ultrasonography. Iowa, Blackwell Publishing, pp. 181-210. 
Yeager, A.E., Concannon, P.W., 1990. Serial ultrasonographic appearance of post-partum uterine involution in Beagle dogs. Theriogenology 34, 523-535.

Yotov, S., 2011. Application of two-dimensional (Bmode) ultrasonography in the reproduction of sheep. Stara Zagora, Kota Print, pp. 38-43. (BG)
Zduńczyk, S., Milewski, S., Barański, W., Janowski, T., Szczepański, W., Jurczak, A., Raś, A., Leśnik, M., 2004. Postpartum uterine involution in primiparous and pluriparous Polish Longwool sheep monitored by ultrasonography. Bulletin of Veterinary Institute in Pulawy 48, 255-257. 